\title{
ПЕРСПЕКТИВИ ЗАСТОСУВАННЯ МЕТОДИКИ НАРАТИВНОГО ІНТЕРВ'Ю ДЛЯ СУЧАСНИХ ФОЛЬКЛОРИСТИЧНИХ ДОСЛІДЖЕНЬ
}

\author{
Оксана ЛАБАЩУК
}

Доктор філологічних наук, професор Тернопільського національного педагогічного університету імені Володимира Гнатюка, Україна

\section{DOI 10.25128/2304-1222.19.48.05}

Narrative interview method is promising for contemporary Folkloristics in particular for the study of personal autobi ographical narratives. Thepaper focuses on the peculiarities of folklorematerial fixation, the method of autobiographical narratives recording and certification, as well as the ethical requirements associated with the disclosure of the narrator's personal data.

Keywords: autobiographical narrative, performance, editorial practice, context, recording technique, narrative interview, folk kore material.

Методика наративного інтерв'ю $є$ перспективною для сучасної фольклористики, зокрема для дослідження персональних автобіографічних наративів. У статті приділяється увага особливостям фіксації фольклорного матеріалу, методиці запису та паспортизації автобіографічних наративів, а також звернено увагу на етичні вимоги, пов'язані з оприлюдненням особистих даних оповідача.

Ключові слова: автобіографічний наратив, виконання, едииійна практика, контекст, методика запису, наративне інтерв'ю, фольклорний матеріал.

Metodyka przeprowadzenia wywiadu narracyjnego jest perspektywiczna we współczesnej folklorystyce, min. przy badaniach personal nych narratywów autobiograficznych. W artykule uwaga została skupiona na specyfice identyfikacji materiału folklorystycznego, metodom notacji i ewidencji narratywów autobiograficznych, a także wymaganiom etycznym powiązanym $z$ ujawnieniem danych osobowych narratora.

Słowa kluczowe: narratyw biograficzny, realizacja, praktyka edytorska, kontekst, metody notacji, wywiad narracyjny, materiat folklorystyczny.

Сучасна фольклористика ставить перед дослідниками завдання не лише кількісного нагромадження джерельної бази, але передусім пошуків нових підходів до збирання, запису й архівування матеріалу. Це пов'язано і з новими технічними можливостями, і з тими змінами, що їх сьогодні зазнає фольклорна система загалом. Зрозуміло, що, окресливши нову парадигму підходів до розуміння фольклору, ми повинні вибрати оптимальні методи фіксації сучасного фольклорного матеріалу. Традиційно фольклористика спиралася на його кількісне нагромадження. Вважали, що потрібно зафіксувати, вберегти від зникнення якнайбільшу кількість текстів у 
якнайбільшій кількості варіантів. Для збирацької роботи широко застосовували різноманітні анкети й питальники, які допомагали алгоритмізувати роботу збирача. Сучасні вимоги до фіксації фольклорного тексту визначають, що коректним є запис у природній формі його побутування, з урахуванням контексту. Цінність окремого запису визначається повнотою його виконання, якістю фіксації на аудіо- та відеоHосії.

Перші спроби звернути увагу на контекст фольклорного виконання, налагодити природний характер перетікання фольклорної інформації від оповідача до збирача були зроблені українськими фольклористами ще у XIX столітті. Теоретичні здобутки української фольклористики XIX століття С. Росовецький вбачає зокрема у розробці «філософії фольклористичного контакту», започаткованої П. О. Кулішем, який «серйозно міркував про засади такої збирацької методики, що мала б якомога природніший характер, не деформувала би... притаманної усній традиції форми реалізації твору» [Росовецький 2005: 88]. Саме Пантелеймон Куліш вперше в українській фольклористиці намагався налагодити такий контакт із виконавцем фольклорного твору, який би максимально наблизив ситуацію виконання до природної. Ось як про це згадує сам фольклорист: «Я не поспішав випитувати у нього все, що він знав або пам'ятав. Мені здавалося, що буде дуже добре, коли я буду записувати його роздуми і розповіді в міру того, як вони будуть довільно виказуватися переді мною» [Кулиш 1857: 8].

Такий підхід до збирацької роботи обстоювало чимало дослідників XX століття, зокрема Е. Файн [Fine 1994] та П. Г. Богатирьов [Богатырев 2006]. Детально здобутки та переваги контекстуального методу у фольклористиці проаналізовано у монографії О. Ю. Бріциної [Бріцина 2006]. У роботах дослідниці звернено увагу передусім на виконавський контекст фольклорного тексту: «Контекст виконання (контекст ситуаціï) включає обставини виконання, аудиторію, iі запити (як передбачені виконавцем, так і безпосередньо артикульовані слухачами), а також низку інших зовнішніх факторів. <.. > Виконавський контекст включає невербальні складові усного тексту (голос, темп, ритм, інтонацію, жести, міміку та інші особливості манери виконання)» (Вирізнення у тексті курсивом - автора. - О. Л.) [Бріцина 2006: 74]. Урахування контексту виконання робить неможливим поділ записів фольклорних творів на «повні», «художньо досконалі» та «неповні», «неестетичні». 
Будь-який неповний текст доповнюється контекстом, сприймається аудиторією та є «достатньо досконалим для даної ситуації». Інша справа, що при публікації такого твору укладач повинен компенсувати фольклорний текст коментарями, які прояснюють контекст виконання для читачів [Бріцина 2006: 74-75].

Посилаючись на здобутки західноєвропейської та американської фольклорної школи, дослідниця виділяє три можливі різновиди контекстів запису фольклорного твору: натуральний, штучний та індукований. Сучасна фольклористика вважає інформативним для дослідника не лише натуральний, а й будь-який інший різновид контексту. Для науковця, насамперед, важливо те, що текст в процесі виконання виявляє свої контекстуальні зв' язки. Важливо лише, щоб умови запису та тип контексту були чітко зафіксовані збирачем та враховувалися при науковому аналізі [Брицына 2010: 75].

Протягом останнього десятиліття в Україні активізується науковий інтерес фольклористів до записів та публікацій автобіографічних спогадів, що мають виразну соціально-історичну проблематику. Зокрема розвідки Оксани Кузьменко засвідчують суспільну вагу інформації, зафіксованої в усних наративах. Увагу дослідниці привертають народні оповіді про Першу світову війну, серед яких вона прагне побачити традиційні фольклорні сюжети. О. Кузьменко цікавить передусім історичний досвід народу, а не приватний, особистий досвід. Однак акцентування уваги на важливості у таких розповідях не передачі інформації, а «передачі почуттів, переживань очевидця, учасника події, зображення емоційного стану оповідача», а також усвідомлення того, що такі історії розповідають про людину в «межових ситуаціях», видається нам доволі значущим і симптоматичним. [Кузьменко 2008: 233].

Грунтовне дослідження Романа Кирчіва «Двадцяте століття в українському фольклорі» торкається питання біографічних наративів про Першу світову війну, українські визвольні змагання у міжвоєнне двадцятиліття, жахіть голодомору та Другої світової війни [Кирчів 2010]. Уважне ставлення дослідника до особливостей фольклорної прози ХХ століття дозволяє йому зробити висновок про те, що «у прозі на перше місце виходять усне оповідання, меморат» [Кирчів 2010: 40]. Р. Кирчів зосереджує увагу на змістовому наповненні таких розповідей: «В останні десятиліття в системі жанрів неказкової прози утвердилося т. зв. “усне оповідання”, зміст 
якого зосереджений на оповіді про те, що бачив, переживав, свідком чого був сам оповідач [Кирчів 2010: 50-51].

Сучасні англомовні публікації також засвідчують значний потенціал автобіографічних наративів для фольклористичних досліджень [Atkinson 1995; Kirshenblatt-Gimblett 1989; Oring 1987; Titon 1980].

Автобіографічний наратив не є самостійним жанром фольклору, однак, дуже часто практично усі жанри неказкової прози є «вписаними» у загальну канву автобіографічної оповіді. Попри низку дослідницьких завдань, які випливають саме 3 такого припущення, передусім постає проблема коректної фіксації матеріалу. Оптимальним, на наш погляд, для запису автобіографічного наративу є індукований контекст. Цей тип контексту передбачає створення ситуації, максимально наближеної до натуральної, коли інформатор за 10-15 хвилин роботи зі збирачем перестає помічати записувальний пристрій, вбачаючи у фольклористі лише зацікавленого співрозмовника. Саме такий підхід - фіксацію довільної розповіді, розмови-діалогу чи полілогу - ми пропонуємо застосовувати. Відмовившись від анкетного принципу, коли один з комунікантів лише запитує, а другий відповідає, ми надаємо розмові тональності, властивої невимушеній бесіді двох чи кількох осіб.. Оскільки усний наратив, як виявилося, $є$ надзвичайно чутливим до прагматики ситуації розповідання, головною проблемою збирача було наблизити розповідь до тої форми, якої вона набуває у натуральному контексті.

Дещо інший підхід при дослідженні сучасних міських наративів застосувала I. С. Вєсьолова. Відмовившись від роботи з анкетою, вона використала принцип «включеного спостереження», або натурального контексту, коли виникнення текстів провокувалось лише щирою зацікавленістю слухача. Більшість текстів записано в природному комунікативному середовищі збирача. До недоліків такого методу (i тут ми повністю погоджуємося з дослідницею) Вєсьолова зараховує невелику кількість зібраних текстів - їх лише 30, а також те, що не завжди можна використати диктофон, відповідно деякі записи доводиться робити з пам'яті [Веселова 2000: 8].

Отже, запис в умовах натурального контексту, при всій його науковій привабливості, неефективний: він потребує значних затрат часу, але все одно не дає змоги зібрати достатню кількість матеріалу, щоб відстежити дійсний стан традиції. Тому 
на практиці значно частіше застосовують анкети і питальники, які укладаються відповідно до цілей та наукових зацікавлень збирача і вміщують поширені в даній місцевості сюжети.

Принцип роботи з анкетою застосувала у своїй кандидатській дисертації російська дослідниця Катерина Бєлоусова. Матеріалом для ії дослідження стали сто інтерв'ю з жінками, які мають досвід народження дітей. Інтерв'ю проводилися за допомогою спеціально складеної анкети, в основу якої було покладено композиційну схему типової, на думку дослідниці, розповіді про пологи. Питання в анкеті вона розмістила в такому порядку, щоб відповіді на них утворювали більш-менш зв'язну історію про пологи. Таким чином, вважає К. Бєлоусова, «створюються умови, що максимально наближають процес анкетування до природної ситуації відтворення розповіді про пологи» [Белоусова 1999: 4]. Однак характер розповіді (послідовність викладу, повнота використання тих чи інших мотивів) залежить від умов виконання. Тому тексти, записані з використанням методу анкетування, не можуть бути використані для аналізу структури чи прагматики наративу, вони певною мірою відображають лише його семантику. Як правило, людина пригадує історію, що містить лише кілька мотивів, зафіксованих у іï пам'яті як найважливіші. На нашу думку, використання анкети аж занадто скеровує оповідача, тож збирач, зазвичай, отримує те, що хоче почути. На небезпеку нав' язування дослідницької позиції носію фольклорної традиції при записі матеріалу звернула увагу й російський антрополог В. І. Харитонова [Харитонова 1999]. Ця небезпека є суттєвішою при записі слабоформалізованих неклішованих текстів, зокрема фольклорної прози.

Російський етнолог Тетяна Щепанська, досліджуючи роль вагітності та пологів у житті сучасної жінки з точки зору культурної антропології, використовувала такі джерела: особисті записи жінок, які проводилися ними під час вагітності, пологів, годування дітей грудьми, щоденники, приватні листи жінок-матерів, дані включеного спостереження, зроблені жінками-етнологами, а також дані традиційної селянської культури. Для дослідниці було важливо отримати автентичні тексти, «які циркулюють в даному середовищі без участі дослідника. Особлива увага приділялася фіксації фольклорних (і загалом жанрово стереотипізованих) текстів: прикмет, порад, тлумачень сновидінь» тощо [Щепанская 1994 16]. 
Завдання фольклористичного дослідження вимагають, щоб оповідачі розповідали свої історії у формі, максимально наближеній до їх природного побутування. Водночас науковцю потрібно було зібрати достатню кількість текстів, аби мати можливість зробити спостереження і висновки відповідно до мети і завдань своєї роботи. Саме тому нашу увагу повинні привернути напрацювання спеціалістів інших дисциплін, які вивчають усні автобіографічні тексти. Розповідь про пережитий досвід, або автобіографічна розповідь, є об'єктом дослідження для представників багатьох наук: антропологів, культурологів, психологів, соціологів, а також учених, які працюють у галузі усної історії.

На перспективності підходів, які пропонує усна історія, наголошує Оксана Кісь: «Світова практика показує, що за умови належного дизайну такого дослідження (обгрунтованої методологічної бази, обрання релевантної методики та застосування адекватних технік інтерв'ю) і належного документального оформлення (паспортизації, транскрибування, архівування), усні історичні джерела мають величезний дослідницький потенціал» [Кісь 2012: 28]. Окремі дослідники наголошують на важливості застосування методу автобіографічного інтерв'ю у фольклористиці [Кухаренко 2010] та демонструють продуктивність зазначеного підходу на власному матеріалі [Simonides 1989].

Зосередимося на тих підходах, які пропонують усні історики. Спільний об'єкт дослідження - усні історії про пережите - дозволяють фольклористу звертатися до напрацювань, здійснених в рамках досліджень усної історії. Ця наукова дисципліна в Україні сьогодні розвинулась в окремий напрямок соціально-історичних досліджень. Напрацювання в галузі усної історії допомагають зрозуміти, як за індивідуальним життєвим досвідом побачити універсалії та загальні закономірності. Відмінність лише в тому, що ці загальні закономірності усні історики шукають в площині історичного чи соціального минулого, а фольклористи - в площині антропології культури та особливостях, у тому числі художніх, творення тексту. Одним 3 основних досягнень усної історії, яке фольклористи повинні запозичити для своєї роботи, є методика збору дослідницького матеріалу за допомогою наративного інтерв'ю. Варто наголосити: наративне інтерв'ю як базовий принцип для збору матеріалів дозволяє акцентувати увагу саме на антропологічному підході до роботи, що 
передбачає висвітлення ролі людини в культурних та суспільних процесах, забезпечує відхід від позитивізму та об'єктивізму. Хоча описаний метод і накладає на дослідників певні обмеження, адже, як слушно зауважують А. Нагачевський та М. Маєрчик, «...пам'ять химерна, та й сам процес інтерв' ювання служить активним фільтром відбору і конструювання інформації» [Нагачевський 2010: 303], ми все ж вважаємо за доцільне використовувати його у фольклористиці.

Методика проведення наративного інтерв'ю передбачає таку послідовність дій збирача: постановка відкритого запитання, уважне слухання розповіді, невтручання у розмову змістовними репліками (дозволяються лише фрази, які підтверджують активну зацікавленість слухача розмовою). Після закінчення інтерв'ю дозволяється ставити спочатку відкриті, а потім закриті запитання. Тексти, отримані шляхом наративного інтерв'ю, повинні бути записані на цифрові носії інформації, а потім затранскрибовані (розшифровані). Корисною для фольклориста виявиляєтьсяся і методика опрацювання зібраного матеріалу — членування почутих історій на окремі блоки, сегменти, що полегшує подальшу дослідницьку інтерпретацію [Грінченко 2006].

В істориків варто запозичити ще один важливий елемент дослідницької роботи, пов'язаний з особливостями інтерпретації зібраного матеріалу: «Будь-який елемент людської культури вартий уваги дослідника, якщо він трапляється неодноразово (не менше трьох разів) в умовах польових спостережень або у різних інформантів» [Пушкарева 2010: 46].

Опишемо детально методику запису матеріалу, яку доцільно використовувати, записуючи автобіографічні розповіді. Процедура збирання матеріалу повинна здійснюватися із застосуванням методики наративного інтерв'ю. Заздалегідь, переважно за декілька днів, необхідно отримати у респондента попередню згоду на інтерв' ювання та домовитися з ними про зустріч. На початку розмови інтерв' юер звертається до співрозмовника з проханням: «Розкажіть мені про ваше життя, усе, що ви пам'ятаєте про своє минуле». Під час інтерв'ю збирач не втручається в розмову, лише окремими репліками («так», «розумію», «ага») підтверджує своє зацікавлення розповіддю. Час від часу інтерв' юер робить у записнику нотатки про те, які моменти варто було б уточнити, які сюжети, виходячи з особистого досвіду людини, мо- 
гли би бути їй цікаві чи відомі. Лише після завершення розповіді ставляться додаткові запитання для отримання повнішої інформації, актуальної для дослідження. Усі інтерв'ю повинні записуватися на цифрові носії, а потім розшифровуватися (транскрибуватися).

При публікації матеріалів автобіографічного характеру особливо гостро постало етичне питання. Традиційно у фольклорних збірниках детально вказуються паспортні дані інформанта. Записані розповіді як правило містять багато особистих подробиць 3 життя людини, які є суттєвими, і які неможливо опустити. Однак оприлюднювати особисті історії, на нашу думку, неетично. Для вирішення цієї дилеми звернімося до досвіду зарубіжних колег. Так, дослідниця Джейн Завіска зазначає, що зараз в антропології та соціології США та Великої Британії порушують питання етики польової роботи. Традиційно держава фінансує спеціальні комісії при університетах, які покликані «гарантувати, що дослідники дотримуються правил етики» [Зависка 2006: 173]. У «Белмонтському звіті» Конгресу Сполучених Штатів Америки викладено три принципи, яких потрібно дотримуватися при плануванні і проведенні дослідницької роботи: повага до людей, милосердя і справедливість. Перший принцип означає, що людина має право вибирати, чи погоджується вона брати участь у дослідженні та надати свою згоду на участь у роботі, також їй повинні пояснити, у чому полягатиме їі участь, розповісти про мету і суть наукового проекту. Принцип милосердя виявляється в оцінці можливого блага для досліджуваних та мінімізації можливих ризиків. Принцип справедливості полягає у відповіді на питання, хто саме отримає вигоду від проведеного дослідження [Зависка 2006: 173174].

Отже, нове розуміння природи сучасного фольклору вимагає нових підходів до запису текстів. Перспективи використання фольклористами методу автобіографічного інтерв'ю викликають у дослідника ряд запитань як організаційно-методичного, так і етичного характеру. Оптимальним для фольклориста, який записує автобіографічну оповідь, виявилося використання наративного інтерв'ю, а також методу включеного спостереження. Розповіді про особисте життя містять приватну, навіть інтимну інформацію з життя людини та їі сім'ї, тому з етичних міркувань ці дані не підлягають оприлюдненню. 


\section{ЛIТЕРАТУРА}

Белоусова, Е. А. Представления и верования, связанние с рождением ребенка: современная городская культура: автореф. дис. ... канд. культурологии. Москва 1999.

Богатырев, П. Г. Роль ситуации при исполнении фольклорных призведений // Функционально-структуральное изучение фольклора (Малоизвестные и неопубликованные работы), Москва 2006, с. 218-226.

Бріцина, О. Ю. Українська усна традиційна проза: питання текстології та виконавства, Київ 2006.

Брицына, А. Ю. Исполнитель текст контекст (о методологической доминанте и практическом смысле интереса собирателя к контексту исполнения // Фольклор: Текст и контекст. Сборник статей, отв. ред. А. С. Каргин, Москва 2010, C. 67-79.

Веселова, И. С. Жанры современного городского фольклора: повествовательные традиции: автореф. дис. ... канд. филол. наук, Москва 2000.

Грінченко, Г. Усна історія: методичні рекомендації з організації, Харків 2006.

Зависка, Дж. Этика полевой работь в этнографии, «Антропологический форум», 2006, № 5, с. 169-193.

Кісь, О. Жінка в традиційній українській культурі (друга половина XIX - початок ХХ ст.), Львів 2012.

Кирчів, Р. Двадцяте століття в українському фольклорі, Львів 2010.

Кузьменко, О. Психологія поведінки украӥнців в народних оповіданнях про Першу світову війну (за польовими матеріалами з архіву В. Гнатюка), «Studia methodologi са», 2008, вип. 25, с. 233-236.

Кулиш, П. А. Записки о Южной Руси : в 2 т., Санкт-Петербург 1856-1857, т. 1, 1856, XXVI.

Кухаренко, С. Стислий огляд фольклористики в Північній Америиі: теорії, підходи, парадигми, «Народознавчі зошити», 2010, № 3-4, с. 310-315.

Нагачевський, А. Особливості украӥнської фольклористики в Канаді, «Народознавчі зошити», 2010, № 3-4, с. 293-309.

Пушкарева, Н. Л. Устная история: гендерный аспект // У пошуках власного голосу: Усна історія як теорія, метод та джерел: зб. наук. ст., за ред. Г. Грінченко, Н. Ханенко-Фрізен, Харків 2010, с. 39-49.

Росовецький, С. Український фольклор у теоретичному висвітленні: посібник для університетів, Київ 2005, ч. 1: Теорія фольклору.

Харитонова, В. И. Заговорно-заклинательное искусство восточных славян: проблемы традиционных интерпретаций и возможности современных исследований, ч. 1-2, Москва 1999.

Щепанская, Т. Б. Мир и миф материнства: Санкт-Петербург, 1990-е г2. (Очерки женских традищий и фольклора), «Этнографическое обозрение», 1994, № 5, c. 15-27.

Atkinson, R. The Gift of Stories: Practical and Spiritual Applications of Autobiography, Life Stories, and Personal Mythmaking, Westport 1995.

Fine, E. C. The Folklore Text: From Performance to Print, Bloomington - Indianapolis 1994. 
Kirshenblatt-Gimblett, B. Authoring Lives, "J ournal of Folklore Research", 1989, Vol. 26, No 2, pp. 123-149.

Oring, E. Generating Lives: The Construction of an Autobiography, "Journal of Folklore Research", 1987. Vol. 24, № 3, pp. 241-262.

Simonides, D. Opowiadania ludowe, w: Folklor Górnego Sląska, pod. red. Doroty Simonides, Katowice 1989, s. 335-416.

Titon, J. T. The Life Story, “The J ournal of American Folklore”, 1980, Vol. 93, No. 369. pp. 276-92. 